UDC $32.001(075.8)$

DOI: $10.17721 / 2415-881 \times .2019 .82 .82-88$

\author{
Anatoly Tkach \\ Postgratuat of kathedra of global communications, University «Ukraine» (Kyiv, Ukraine) \\ https://orcid.org/0000-0003-3254-8161 \\ e-mail: tio19@ukr.net
}

\title{
US POLICY AND DEMOCRACY CHALLENGES IN LATIN AMERICA AND THE CARIBBEAN
}

\begin{abstract}
Formulation of the problem: In the article management problems are examined Geographic proximity has ensured strong linkages between the United States and Latin America and the Caribbean, based on diverse U.S. interests, including economic, political, and securityT concerns. The United States is a major trading partner and the largest source of foreign investment for many countries in the region, with free-trade agreements enhancing economic linkages with 11 countries.

Purpose of the research: The region is a large source of U.S. immigration, both legal and illegal; proximity and economic and security conditions are major factors driving migration. Curbing the flow of illicit drugs has been a key component of U.S. relations with the region for more than three decades and currently involves close security cooperation with Mexico, Central America, and the Caribbean. U.S. support for democracy and human rights in the region has been long-standing, with particular current focus on Cuba, Nicaragua, and Venezuela.

The article analyzes the priorities of Administration of President Trump ordered U.S. withdrawal from the proposed Trans-Pacific Partnership trade agreement, which would have increased U.S. economic linkages with Mexico, Chile, and Peru. President Trump criticized the North American Free Trade Agreement (NAFTA) with Mexico and Canada as unfair, warned that the United States might withdraw, and initiated renegotiations; ultimately, the three countries agreed to a United States-MexicoCanada Agreement in late September 2018. The proposed agreement, which requires congressional approval, largely leaves NAFTA intact but includes some updates and changes, especially to the dairy and auto industries. Administration actions on immigration have caused concern in the region, including efforts to end the deportation relief program known as Deferred Action for Childhood Arrivals (DACA) and Temporary Protected Status (TPS) designations for Nicaragua, Haiti, El Salvador, and Honduras. President Trump unveiled a new policy in 2017 toward Cuba partially rolling back U.S. efforts to normalize relations and imposing new sanctions.
\end{abstract}

Key words: demokracy; political process; global events; associated construction; effective source; government 
УДК $32.001(075.8)$

DOI: $10.17721 / 2415-881 x .2019 .82 .82-88$

\title{
Ткач Анатолій Олегович
}

Здобувач кафедри суспільно-політичних наук, глобалістики та соціальних комунікацій, університет «Україна» (м. Київ, Україна)

https://orcid.org/0000-0003-3254-8161

e-mail: tio19@ukr.net

\section{ПОЛІТИКА США ТА ВИКЛИКИ ДЕМОКРАТІЇ В ЛАТИНСЬКІЙ АМЕРИЦІ ТА КАРИБСЬКОМУ БАСЕЙНІ}

\begin{abstract}
Резюме
Метою дослідження є визначення складових відносин США та країн Латинської Америки, демократичного управління в країнах Латинської Америки за умов авторитарних та демократичних режимів. Автор аналізує авторитарні стратегії економічного та політичного управління. Особлива увага приділена розвитку відносин у контексті політичних та економічних наслідків авторитаризму.

Результати та висновки Географічна наближеність забезпечила міцні зв'язки між США та країнами Латинської Америки на основі різноманітних інтересів США, включаючи економічні, політичні та проблеми безпеки. США є основним торговим партнером і найбільшим джерелом іноземних інвестицій для багатьох країн регіону, з угодами про вільну торгівлю, які посилюють економічні зв’язки з 11 країнами. Регіон $є$ джерелом імміграції США, як легальної, так і незаконної; близькість та економічні та безпекові умови є основними факторами, що сприяють міграції. Стримування потоку незаконних наркотиків $є$ ключовим компонентом відносин США 3 регіоном протягом більше трьох десятиліть і в даний час передбачає тісне співробітництво 3 Мексикою, Центральною Америкою та Карибським регіоном. США підтримують демократію та права людини в регіоні давно, з особливою увагою до Куби, Нікарагуа та Венесуели. Відповідно до Адміністрації Трампа, перспективи відносин США з регіоном змінилися. Адміністрація запропонувала глибоке скорочення допомоги регіону. Щодо торгівлі, президент Трамп наказав США вийти з запропонованої торговельної угоди TransPacific Partnership, яка збільшила б економічні зв'язки США з Мексикою, Чилі та Перу. Президент Трамп критикував Північноамериканську угоду про вільну торгівлю (НАФТА) з Мексикою та Канадою, як несправедливих, попередив, що США можуть вийти, і розпочали переговори; три країни погодилися на угоду США-Мексика-Канада наприкінці вересня 2018 p.
\end{abstract}

Ключові слова: політичний режим; політичний процес; глобальні події; економічна криза; інтеграція

\section{Introduction}

The Latin American and Caribbean region has made significant progress compared to the last three decades in terms of both political and economic development (33 countries, from the Caribbean country of St. Kitts and Nevis, one of the smallest states in the world, to the South American giant, Brazil). Most regimes are democracies, at least formally. The threat to elected governments of their own military is scattered in most countries. Free and fair elections have become the norm in most 
countries in the region, although elections in several countries have been controversial in 2017. The Bahamas, Ecuador and Chile have held successful presidential elections. However, the elections in Honduras in November 2017 were marked by significant irregularities. The Secretary-General of the Organization of American States (OAS) has called for new elections. Despite a series of mass civil protests, incumbent President Juan Orlando Hernandez was certified as the winner in December 2017.

\section{Research methods}

The following research methods were used to address the issues set in the article: general scientific methods - descriptive, system, structural-functional, comparative, institutional-comparative; general logical methods - empirical, statistical, prognostic modeling and analysis; special methods of political science.

\section{Results and discussion}

Despite significant improvements in political rights and civil liberties, many countries in the region are still facing problems. In a number of countries, weaknesses remain in the capacity of the state to provide public services, to ensure accountability and transparency, to enhance the rule of law and to ensure the security of citizens.

In recent years, the quality of democracy has deteriorated in a number of countries in the region. One of the factors contributing to this democratic erosion is the rise of organized crime. Organized crime is particularly affected Mexico and several Central American countries due to increased use of the region as a transit area with the growth of corruption, crime and violence. A factor that has a negative impact on democracy in several countries is the abuse of power by the executive branch. Elected leaders sought to consolidate power at the expense of minority rights, which led to the loss of liberal-democratic practices. Venezuela stands out because the government of President Nicolas Maduro forcibly suppresses the opposition and manipulates government agencies to retain power. In recent years, media freedom has deteriorated in some countries as a consequence of increased violence, connected with organized crime, and political attempts to curb critical or independent media. In 2017, Cuba's gross domestic product (GDP, current prices) was $\$ 96.9$ billion, and GDP per capita was $\$ 8,617$ [1, p. 23].

Cuba has no direct elections for its head of government. Instead, the Cuban legislature elects members of the 31-member state council, and the president of that body serves as the head of the Cuban government and the head of state.

In Peru, President Martin Viscarra stepped down in March 2018 following the resignation of Pedro Pablo Kuchinsky (2016), who was impeached on April 19, 2019 by the Supreme Court of Peru for corruption.

Former President of Peru 69-year-old Alan Garcia (President 1985-1990, 2006-2011) dismissed corruption charges in a suicide note. He called his death «a sign of contempt for the enemy», committed suicide, and wrote in his suicide note that he was not guilty of corruption [2, p. 17].

The Freedom House praised Ecuador's President L. Moreno for relinquishing his «often repressive power» to his predecessor, Raphael Correa; to reduce pressure on the media; and suggest renewal of time limits. At the beginning of February 2018, a referendum on time limits and other reform measures was approved. Freedom House report also praised the reform measures to limit preColombian hydrocarbons yaznennya and the continued expansion of government control in areas previously controlled by the left. insurgents under the Government's Peace Agreement of 2016 with the Revolutionary Armed Forces of Colombia (FARC) [3, p. 25].

On the downside, Freedom House drew attention to events in Venezuela, Bolivia, Honduras, Nicaragua and Mexico in 2017. the country's constitutional court, which overturned the 2016 presidential term that was supported by the 2016 referendum; terms would limit current President E. Morales to seek a fourth term. Freedom House has criticized Honduras for the flawed presidential 
election in November 2017, which delayed the early vote count and canceled an early vote count and won the incumbent president. The situation in Nicaragua has worsened in 2018. Since April, opposition to Ortega's board has grown; the government and its supporters have severely suppressed this opposition, the activities of journalists and civil society activists who have threatened to expose corruption in society. The index classifies countries as full democracies, flawed democracies, hybrid regimes and authoritarian regimes based on the ratings of 60 indicators covering the electoral process and pluralism, civil liberties, functioning of government, political participation and political culture $[4$, p. 23].

In its democracy index EIU considers 24 countries in Latin America Caribbean Ba The EIU classified Cuba and Venezuela as authoritarian regimes in 2017. In its first index, Venezuela was reduced to authoritarian because of its «prolonged fall to dictatorship» and the cruel suppression of the dictatorship [5, p. 28].

In its Democracy Index 2018, the EIU added Nicaragua to the list of authoritarian countries, citing a «pro-aggressive crackdown» adopted by pro-government forces that led to numerous human rights abuses and the deaths of over 300 people [6, p. 86].

EIU Index 2018 ranked Five countries in the region-Bolivia, El Salvador, Guatemala, Haiti and Honduras - as hybrid regimes or countries characterized by weak rule of law, weak civil society, and often widespread corruption. The 2018 index also classified two countries in the region, Costa Rica and Uruguay, as full democracies and 14 countries as imperfect democracies, or countries that have free and fair elections and respect basic civil liberties but show weaknesses in other aspects of democracy. The report notes that governments in the region continue to face corruption and the effects of transnational organized crime and that «persistent governance and democratic deficiencies have given way to a decline in confidence in government, formal political institutions, and democracy itself. She also noted the return of populism to Mexico and Brazil, as frustrated voters in both countries turned to populist candidates.

Some countries in the region have experienced deeper recessions than others in 2009 integrated with the US economy (Mexico); other countries with more diversified trading and investment partners experienced smaller declines.

In January 2019, the IMF estimated that economic growth in Latin America and the Caribbean declined somewhat to $1.1 \%$ in 2018 and is projected to increase to $2 \%$ in 2019 and $2.5 \%$ in 2020 . In 2018, the IMF forecast $1.9 \%$ of regional growth for the year. However, the continuing economic downturn in Venezuela and the ongoing economic challenges in a number of countries have slowed growth [7, p. 17].

Latin America has made significant progress in combating poverty and inequality from 2002 to 2014. Extreme poverty (currently defined by the World Bank as living at less than $\$ 1.90$ per day) also declined over this period, from $11.2 \%$ in 2002, representing 57 million people, to $7.8 \%$ in 2014 . year or 46 million people This decrease has led to an increase in per capita income and targeted government spending known as contingent money transfer programs for vulnerable sectors [8, p. 29].

Since 2015, Latin America's poverty rate has increased to $30.2 \%$ of the region's population in 2017, or 184 million. Similarly, extreme poverty in Latin America increased to 10.2\% in 2017, at 62 million. Poverty reduction can be largely attributed to the economic setbacks in Brazil and Venezuela, both of which have seen significant declines in per capita income, according to the US Economic Commission for Latin America and the Caribbean. In contrast, poverty reduction continues from 2015 in several countries in the region, including Five countries, which in 2016 and 2017 respectively fall in poverty percentage was: Argentina, Colombia, Costa Rica, El Salvador and Paraguay. 
Latin America and the Caribbean: real GDP growth, 2016-2020 (in percent)

\begin{tabular}{|c|c|c|c|c|c|}
\hline & 2016 & 2017 & 2018 score & 2019 project & 2020 project \\
\hline Brazil & $-3,5$ & 1,1 & 1,3 & 2,5 & 2,2 \\
\hline Mexico & 2,9 & 2,1 & 2,1 & 2,1 & 2,2 \\
\hline LACB & $-0,6$ & 1,3 & 1,1 & 2,0 & 2,5 \\
\hline
\end{tabular}

Source: International Monetary Fund, World Economic Outlook, October 2018. (International Monetary Fund, World Economy Outlook, October 2018)

In connection connection with the absence of Congressional action on comprehensive immigration reform, President Obama addressed the execution in 2012 with a program known as Deferred Detachment for Children (DACA) that provided deportation relief for some immigrants who came as children. The Obama administration also granted Temporary Protected Status (TPS) to Haitians in the United States in 2010 after the earthquake.

Gallup's opinion poll on world views on US leadership showed that in the Western Hemisphere, $58 \%$ did not approve of US leadership and $24 \%$ approved. This result was a significant change from 2016, when a Gallup poll found that 27\% disapproved of US leadership and 49\% disapproved. The 2018 Pew Research Center World Survey included Argentina, Brazil and Mexico — in all three countries confidence in the US president was one of the lowest in the world. In terms of favorable US views, 32\% in Argentina and Mexico had favorable views and 55\% in Brazil had favorable views [9, p. 11].

The Trump administration has taken steps that have changed the dynamics and prospects of US relations with Latin America and the Caribbean. The Department of State set the framework for US policy on the region in February 2018, reflecting the continuity of long-term US objectives in the region. The framework, however, seems to contradict some of the administration's actions, sometimes accompanied by rigid rhetoric, on immigration, trade and foreign assistance. Despite the cancellation by President Trump of his scheduled participation in the Summit of America in Peru in April 2018, was lost opportunity to collaborate with hemisphere leaders (Vice President Mike Pence represented the US at the summit).

Regarding trade issues, the president dismissed Trump long-term policy of previous administrations to enhance economic-called bonds with Latin America through reciprocal free trade agreement. He called past free trade agreements harmful to US workers, industries and promised to revise new «fair and reciprocal» agreements. President Trump orders the US to withdraw from the proposed TransPacific Partnership Trade Agreement (CCI) in January 2017; the deal would increase economic-called bandages US from Mexico, Chile and Peru. Similarly, the President sharply criticized NAFTA and repeatedly warned that the United States could withdraw from the agreement with Mexico and Canada. By the end of September 2018, all three countries had agreed on a proposed new US-Mexico-Canada agreement (USMCA) that would leave NAFTA largely untouched, but included some changes, such as provisions for the dairy and automotive industries. The introduction of administrative duties on steel and aluminum imports in 2018 has added new challenges to US trade relations with several countries in the region.

In addition to trade, bilateral relations with Mexico have been tested due to incendiary antiimmigration rhetoric, repeated calls by President Trump for Mexico to pay for the border wall, and the September 2017 administration's decision to end the DACA (potentially affecting several hundred thousand Mexicans. hemisphere). Despite the tensions, common US-Mexican relations remain common, including drug- related security co-operation and efforts to strengthen economic ties, in particular energy co-operation.

Other actions by the Trump Administration on immigration have raised concerns in the region. The administration announced the termination of TPS to 5.3 thousand Nicaraguans in January 2019; up to 58,000 Haitians in July 2019; up to 263,000 Salvadoreans in September 2019; and up to 86,000 
Hondurans in January 2020. Countries have expressed concern about whether they have the capacity to accommodate so many people about the impact of potential deportations on their economies. The administration's actions have led to lawsuits; $r$ in October 2018 a federal court issued a preliminary injunction preventing the suspension of the TPN for Nicaragua, Haiti and El Salvador pending completion of the trial.

Other immigration-related actions, such as the implementation of a zero-tolerance policy on illegal border crossings and the Prosecutor General's decision in June 2018 that migrants demands for gang violence or domestic violence will generally prevent them from receiving asylum, may limit many asylum seekers in Central America.

As for Cuba, in June 2017, President Trump promulgated a new policy that partially undermined some of the Obama administration's efforts to normalize relations. The most significant changes included restrictions on financial transactions with companies controlled by the Cuban military, the abolition of individual travel between people. In the next action on bilateral relations in September 2017. The State Department has downgraded embassies in both capitals in response to incomprehensible injuries to US personnel at the US Embassy in Havana.

With regard to the Caribbean region, the State Department has published a multi-year strategy for US policy on the region, as required by the US and Caribbean Strategic Engagement Act 2016. The strategy has created a framework for deepening relations in six priority areas - security, diplomacy, development, energy, education and health. In the aftermath of Hurricanes Irma and Mary, the United States has allocated $\$ 23$ million to help humanitarian aid to several Caribbean countries and foreign territories.

In Nicaragua, when political unrest against President authoritarian rule. Ortega began to grow in 2018, with the Trump administration strongly opposed the use of violence by the Ortega government and supported the OAS resolution condemning the violence. The administration also applied targeted sanctions (visa restrictions and asset freezes) against several individuals responsible for human rights abuses or significant corruption.

In Guatemala, the administration strongly supported the role of the International Commission on Impunity in Guatemala (CICIG) in 2017, when it was endorsed by the government of President Jimmy Morales. However, in 2018, observers argued that the Administration had not been critical enough as the Morales government continued efforts to weaken the International Commission on Impunity in Guatemala (CICIG). Although a State Department spokesman testified to Congress in July 2018 about the important role of the International Commission on Impunity in Guatemala (CICIG) in strengthening the rule of law, combating impunity and combating corruption in Guatemala, the State Department of the Record Pompeo in September 2018 on US support for CICIG. The statement said that Pompeo and Morales discussed the importance of the Government of Guatemala in cooperation with CICIG, and that the Secretary expressed continued support for the US «reformed CICIG» and pledged to work with Guatemala in the implementation of such reforms in the coming year. Morales announced in early January 2019 that is about to get rid of CICIG. The US Embassy in Guatemala issued a statement expressing concern about future anti-corruption activities in the country, but did not specifically mention the president's actions against CICIG [9, p. 24].

The Trump administration has also warned of China and Russia's activities in the region. The National Security Strategy of the Administration in 2017 states that China «aims to bring the region into its orbit through public investment and loans» and that Russia continues «his failed policies of the Cold War, supporting their radical s Cuban s ally s that» China and Russia supports the dictatorship in Venezuela «and» seeks to expand military ties and arms sales in the region.

The United States supports the fight against drug trafficking and crime, and includes a number of partnerships with other countries in the region: the Merida Initiative, which has led to improved bilateral security cooperation with Mexico; the Central American Regional Security Initiative (CARSI); and the Caribbean Basin Safety Initiative (CBSI). Under the Obama administration, these 
initiatives have combined U.S. counteraction and legal assistance with economic development and violence prevention programs aimed at improving citizens security in the region.

\section{Conclusions}

Much of the economic, political and security issues discussed in this report are likely to support congressional interest in Latin America and the Caribbean at the 116th Congress. Congress is still ahead of the completion of its fiscal year 2011 foreign aid appropriations, which offers significant reductions in regional assistance, and will begin reviewing the Trump Administration's foreign aid request in early 2019.

The United States will pay close attention to the crisis in Venezuela and will consider steps to influence the Venezuelan government's behavior in returning to democratic rule and to alleviate the humanitarian crisis. The proposed US-Mexico-Canada Agreement (USMCA) will face congressional expertise and is likely to be considered at the 116th Congress; Congress must approve the agreement before it can take effect. In Central America, the potential oversight is the effectiveness of US aid to countries of the Northern Triangle, floor related to efforts to combat insecurity, corruption and human rights violations; Of particular concern are efforts to undermine anti-corruption efforts in Guatemala and Honduras, especially the actions of the Guatemalan President against US-backed CICIG. Congress may also potentially consider immigration legislation related to the suspension of TPS for Nicaragua, Haiti, El Salvador and Honduras, as well as the repeal of DACA.

\section{REFERENCES:}

1. ONEI, «Anuario Estadístico de Cuba 2017, Cuentas Nacionales», (2018). 98p. Retrieved from www. cubadebate. cu > noticias $>2019 / 08 / 03>$ on

2. Freedom House, «Freedom in the World. 2018, Democracy in Crisis». (2018). 132 p. Retrieved from https://freedomhouse. org > event > freedom-wor

3. EIU, «Democracy Index 2018: Political Participation, Protest, and Democracy» 2019. - 76p. Retrieved from https://www. eiu. com > topic > democracy-index

4. Economist Intelligence Unit (EIU), «Democracy Index 2017, Free Speech under Attack», (January 2018). 178 p. Retrieved from https://spcommreports. ohchr. org > DownLoadFile

5. Economic statistics in this section are from International Monetary Fund (IMF), World Economic Outlook Database, (2018). 79p. Retrieved from https://www. imf. org > WEO > 2018 > October > English > main-report > Text

6. U.N. Economic Commission for Latin America and the Caribbean, Social Panorama of Latin America 2018. (2019). 193p. Retrieved from https://repositorio. cepal. org > bitstream > handle > S1900050_en

7. Gallup, «Rating World Leaders: 2018, The U.S. vs. Germany, China, and Russia», (2018). - 118 p. Retrieved from https://www. everycrsreport. com > reports

8. U.S. Department of State, «Secretary Pompeo's Call with Guatemala President Jimmy Morales, readout, September 6, 2018. 220 p. Retrieved from https://gt. usembassy.gov > News \& Events

9.U.S. Embassy in Guatemala, «On the Fight Against Corruption in Guatemala», press release, (January 8, 2019). - 112p. Retrieved from https://gt.usembassy.gov > News \& Events 